\title{
Tourism product and destination positioning
}

\author{
Mauro Dujmović, Phd. \\ University of Juraj Dobrila in Pula \\ mduimov@unipu.hr \\ Aljoša Vitasović, Phd. \\ University of Juraj Dobrila in Pula \\ avitasov@unipu.hr
}

DOI:10.5901/mjss.2014.v5n19p570

\begin{abstract}
A modern tourist product, which is adjusted to the needs of new tourists no longer includes a tourist partnership role, but individualisation and personalisation of the experience itself. Should such a base be accepted, it is to be concluded that traditional positioning of destination tourist offers on both macro and micro levels is no longer sufficient, i.e. positioning based on comparative advantages. By traditional positioning, it is not possible to differentiate the tourist offer from the competitors' tourist offer, which ultimately implies a request for competitive tourist offer positioning, enriched by new requirements and needs. Such an approach negates the conventional attitude that the existence and availability of comparative advantages is, in itself, sufficient in order to generate tourist demand and creation of competitive experience economy. Objective of this paper aims to offer a different approach to the competitive positioning of tourist destinations including positioning on the basis of the experience economy. The development of tourist products established on experience as the key exchange value requires an interdisciplinary approach, which, together with the applied marketing activities and competitive positioning through identity affirmation, leads to the tourist offer positioning from the point of view of the experience economy.
\end{abstract}

Key words: tourism destination, positioning, competitiveness, experience.

\section{Introduction}

Tourism is a heterogeneous and dynamic phenomenon is continuously evolving, satisfying the needs of tourism participants and global tourist trends impose a new understanding of tourism and the emergence of «new» tourists. Persons who involve themselves with tourism trends are increasingly experienced today; they express an increasing number of needs, not only within the destination, but also during the journey itself to that destination. Attractive elements of a destination must be complemented by additional activities and the tourist destination excellence is measured strictly by realised experience. It is this diversification of needs and motives itself due to which people choose a visit to a tourist destination and which leads to qualitative detachment from the standard tourist offer. The emphasis is, therefore, on the tourist product quality, thereby realising a qualitative differentiation factor in tourist destination competitive positioning.

In the beginning of its development, tourism was the privilege of a chosen few. It then grew into a social phenomenon which enabled protection of local interests, preservation and presentation of cultural and historical heritage, as well as the differentiation from direct competitors. The result of the described relationships lies in the increase in the quality of life of the domestic population, which must entirely be involved in all the forms of planning and, of course, tourists themselves. The modern tourist product, which is adjusted to the needs of new tourists, is no longer perceived only as a partner role of tourists, but also as individualisation and personification of the experience itself.

Should we accept such a base, we can conclude that traditional tourist offer positioning on macro and micro levels are no longer sufficient. They cannot differentiate domestic tourist offers from competitors' tourist offers, which, ultimately, implies demand for the competitors' positioning of tourist offers, enriched by new demands and needs. Such an approach negates a well-established attitude that existence and availability of natural and cultural heritage is in itself sufficient in order to generate tourist demand and to create a competitive experience economy. 
If we perceive tourism as a social phenomenon, which, on the other hand, demands comprehension of interdisciplinary category, it is necessary to observe it not only on the level of economic sciences, but it is also necessary to widen that observation also to history, political science, sociology, geography and cultural anthropology. Such a wider comprehension implies the insufficiency of mono-comprehension of tourism, where, as a base of observation, the category of growth and not of development, is considered. From that aspect, the area that represents tourist basis should not, at any time, have only exclusively a tourist purpose, although it is the bearer of the tourist function. Therefore, no evaluation methods which are used in areas with dominant tourist function are applicable, but a method of balance between protection and tourist demand, which later also facilitates market differentiation and tourist offer positioning.

While taking into account the main dominant motive for travel as a demand for acquiring an unrepeatable, unique experience, in parallel with the increase in travel, we come across an expansion of a growing number of tourist products based on the experience economy. By means of monitoring of socio-economic trends, i.e. recorded changes in the form of a demographic picture of the society, better education and higher standard of living, a change in the structure of demand for products and services can be noticed. Transition from a service economy to the experience economy occurs; purchase of goods and services is increasingly more frequently replaced by the purchase of experience. Such purchase represents specific reciprocal values for money, which is characteristic for traditional understanding of the experience economy. Development of tourist products based on experience as a key exchange value requires an interdisciplinary approach, which, together with applied marketing activities and competitive positioning by means of identity affirmation, leads to the tourist offer positioning from the aspect of the experience economy.

By this paper, the wish is to affirm the comprehension of tourism as an interdisciplinary and social phenomenon, where the production basis of the tourist product is experience. Furthermore, to contribute to the comprehension of the experience economy as a higher level in the process of economic value progression, within which exchange value is realised. By using elements of the experience economy, differentiation by quality is achieved, with realisation of progression of the added value of the tourist product itself, which results in sustainable and efficient use of the tourist resource basis and that on the example of the small town of Fažana. The optimal model is based on the experience economy and it is implemented on the grounds of the postulates of the theory of competitiveness; it multiply optimises processes in the planning, implementation, monitoring of positioning and management of the tourist product of Fažana, i.e. the tourist offer of Fažana as a destination.

\section{Previous research}

By this paper, the wish is to affirm the comprehension of tourism as an interdisciplinary and social phenomenon, where the production basis of the tourist product is experience and, furthermore, to contribute to the comprehension of the experience economy as a higher level in the process of economic value progression, within which exchange value is realised.

Traditional positioning of the tourist offer on the macro and micro levels is no longer sufficient and cannot differentiate domestic tourist offers from competitors' tourist offers, which, as a rule are enriched by new demands and needs. The modern tourist product of a tourist destination, based on the algorithm of the experience economy, realises a higher level of economic value progression while achieving market differentiation on the basis of the tourist product quality, as a differentiating factor.

If we perceive tourism as a social phenomenon, which, however, insists on the comprehension of the interdisciplinary category, it is necessary to observe it not only on the level of economic sciences, but it is necessary to widen it. Such a wider observation implies the insufficiency of mono-comprehension of tourism, where, as a base of observation, the category of growth and not of development is considered.

Development of tourist products based on experience as a key exchange value requires an interdisciplinary approach, which, together with applied marketing activities and competitive positioning by means of identity affirmation, leads to the tourist offer positioning from the aspect of the experience economy. Such a concept represents one insufficiently researched area so far in domestic science and it needs to be clarified in greater detail.

On the global level, the implemented concept of the experience economy is theoretically still insufficiently researched. Implementation of the concept of the experience economy as a base for competitive positioning of the tourist offer, i.e. tourist destination as a consequence has progression of added value, with the multiplicative effect of tourism. A higher degree of economic development, although with some discrepancies, most frequently is implied by the largest 
possible share of the sector of services in the GDP. Therefore, according to Pine, B.J. and Gilmore, J.H. (1999) the share of the sector of services in the total GDP of national economies (we can draw the analogy with local self-government) represents one of the crucial indicators of economic development.

Absence of the factors of the experience economy in the creation of a contemporary tourist product yields extremely negative results. Historically viewed, the category of national economy competitiveness has suppressed the once dominant category of comparative advantages, equally noticed also in tourism observations, where added value progressively increases when competitiveness is based on the experience economy.

Should we accept the need for interdisciplinary interpretation of tourism as a phenomenon and the economic method necessary for its accurate valorisation, in the given area we find dozens of bibliographical units which perceive the object of research strictly one-sidedly. Competitiveness of tourism and its influence on the category of economic growth is dealt with in a series of scientific and professional works, but is strictly limited to the criteria of competitiveness in tourism, with the absence of alternative solutions. Thus Dwyer, L. et al. (1999) observe the cause-and-effect link of price competitiveness in tourism and journey purpose. Bueno, A. P. (1999) observes the level of competitiveness in tourism through the intensity of the influence the state has on the sector of tourism. In domestic science, Horvat, $\boxminus$. and Kovačević, V. (2004) see the increase in the level of competitiveness in the formation of "clusters". By the same analogy, the experience economy was not systematically monitored within new understandings of tourists, their role and the nature of tourism on macro and micro levels. That is to say that competitive positioning and the experience economy have been observed as two separate phenomena, without interlinks. Pine, B.J. and Gilmore, J.H. (1998) define the best the experience economy as a concept, pointing to the level of added value, which is higher in comparison to the standard exchange service value. Only nine years later, Haemoon Oh et al. join the methods of measurement with application to tourism to the experience economy. With a new perspective of the experience economy, A. Boswijk, T. Thijssen and E. Peelen also introduce the concept of "co-creation", which was based on the so-called DART principle, which Prahalad, C.K. and V. Ramaswamy (2004) explain the best. Interdisciplinary approach to the phenomenon of tourism, with use of the experience economy algorithm in tourist destination competitive positioning as a consequence has realisation of progression of added value. The experience economy, as the fourth phase in the development of economy manages, as opposed to the previous phases, to maximise the progression of added value. In other words, transfer from the service economy to the experience economy occurs.

De-regularised growth of tourist offer irreversibly decreases resource base exchange value and, by the same analogy, also the income from tourism. According to Stiglitz (2000) conceptualisation of tourist offer on the principles of the experience economy represents also a regulatory phenomenon, which not only protects the resource base, but also has an impact on the quality of life of the local population by means of reduction of negative external influences.

Poljanec-Borić, S. and I. Kunst (2008) are the only authors who, in the Republic of Croatia, included the concept of experience economy in their research, where the concept of experience economy is recognised as a differentiating factor in tourist destination competitive positioning. It can be concluded from the above that, in scientific research so far, both abroad and in the Republic of Croatia, this paper problem area has not been entirely dealt with, and not even partially.

Additional study would prove that a systematic implementation of the experience economy algorithm achieves differentiation by quality with repercussion of value-added progression of the tourist product itself, which results in sustainable and efficient use of the tourist destination resource base. The optimal model of tourist destination positioning should, therefore, follow the experience economy algorithm, implemented on the basis of the postulates of the theory of competitiveness, which would lead to a multiple optimisation of the process in planning, implementation, positioning, monitoring and tourist product management, i.e. tourist destination management, as a whole.

In order to approach the tourist offer positioning at all, i.e. the tourist destination positioning on the principle of the experience economy, we need to make the presumption that the development of the entire tourist sector of the Republic of Croatia takes into account the competitiveness factors. For full realisation, it is necessary to implement the following tasks:

- Analysis of the situation and determination of the steadiness of experience economy elements at micro and macro levels,

- Analysis of the level of implementation of the experience economy elements in the current tourist offer of the Republic of Croatia and the county of Istria County 
- Analysis of countries-competitors,

- $\quad$ Analysis of a possibility to apply traditional methods of economic valorisation of the tourist resource basis and economic method of benefit evaluation.

Provided the above tasks are fulfilled, a starting basis would be created for the definition of an optimal model of competition tourist destination positioning and that on the basis of the experience economy.

The most important factors which are essential for tourism development in a destination are: destination accessibility, existence of tourist attractions which are the main motivators for the visit, accommodation and food services, as generic tourist services, as well as the mediation services.

Tourists perceive accessibility as a combination of several factors. In order to make a choice of a destination, it is necessary to provide the potential visitor with sufficient information about its tourist offer and, apart from the information accessibility, a destination must also be accessible by road, sea or air.

\section{Method}

\section{Positioning of Fažana as a tourist destination}

We can define the Municipality of Fažana, i.e. the County of Istria, as exceptionally accessible, given that they have a very favourable geographical position in relation to the main European emissive markets. As for traffic accessibility, the initial advantage has been achieved, as it enables visitors to arrive by all means of transport: road network (Istrian Ipsilon), the sea port of Pula, tourist arrival by sea, as well as the airport in the area of the town of Pula, which facilitates tourist arrivals from all over the world. There is also a railway which is more relevant for transport of goods than as a travel component.

The Municipality of Fažana is increasingly accessible to potential tourists due to numerous promotional activities by the Municipal Tourist Organisation, including its participation in international tourism events and, indirectly, due also to the increasing recognition of the County of Istria as the most attractive destination.

Tourist attractions represent an important factor of the destination itself. We divide the attractions into natural (related to geographical areas) and social, such as cultural and historical landmarks, cultural and sports gatherings, or events themselves. The Municipality of Fažana is a destination which foreign tourists choose because of its natural characteristics, the Mediterranean climate, the sun and clean sea. However, apart from the listed features, Fažana also boasts a whole series of attractions, such as historical and archaeological localities, vicinity of a national park, as well as a large number of events (Small Fishing Academy, Sardine Party, etc.)

Apart from the attractive basis, it is also necessary to provide conditions for accommodating tourists. Destination accommodation capacity includes facilities which provide the services of accommodation (hotels, campsites, private accommodation and other forms), hostelry facilities and other capacities. With the preparation of spatial planning documentation it is ensured that all receptive capacities are, in the best possible way, coordinated with the town events in space, in order to emphasise its individuality.

An optimal tourist organisation must stimulate and direct tourism development in the Municipality of Fažana. The design of an optimal tourist organisation represents the main task for the Municipality of Fažana. The Tourist Organisation work mainly relates to tourist offer advancement and promotion of the destination itself, participation in fairs, both in the country and abroad. Destination publicity greatly helps potential visitors to choose it as their holiday destination, i.e. visitors from emissive countries are acquainted with the destination. The trend is in the positive growth, as increasingly frequent mentioning of Istria as a top destination has had a positive impact on tourism in the Municipality of Fažana, with lower promotional costs.

Based on the analysis of the potentials of the Municipality of Fažana as a tourist destination, as well as the trends in Croatian tourism, strengths, weaknesses, opportunities and threats have been identified and they are united in the SWOT matrix, with the message that "strengths should be stressed, opportunities used, weaknesses reduced and threats avoided". Once the strategic factors have been recognised according to SWOT (Vitasović, 2008, SWOT matrix of the Municipality of Fažana as a destination of cultural tourism), strategies are developed which can be built on the strengths which are able to eliminate the weaknesses, use the opportunities or face the threats. SWOT analysis, however, does not 
show different relationships between external and internal factors, due to which the use of TOWS matrix is recommended. TOWS matrix represents a SWOT analysis variation. In TOWS matrix, different factors are identified, which are later united; for example, opportunities with strengths, with the intention to stimulate a new strategic initiative.

TOWS matrix does not represent the identification of a single best strategy, but it simply generates different strategies, some of which can be implemented. In other words, different alternatives of strategic actions are obtained. Maximaxi (S-O) shows strengths and opportunities, i.e. by existing strengths it is possible to use opportunities. Maxi-mini (S-T) shows strengths in relation to threats, for example, by competition. In fact, the inclination should be to use strengths in order to remove threats, or to bring them to a minimum. Mini-maxi (W-O) shows weaknesses in relation to opportunities. It is necessary to overcome the weaknesses in order to use the opportunities. Mini-mini (W-T) shows weaknesses in comparison with threats. This is an extremely defensive strategy in order to reduce weaknesses and avoid threats.

In construction of the TOWS matrix it is exceptionally important to identify strategic factors, such as competitive positioning, with the aim to achieve value progression. The tendency is that the factor transformation is carried out in accordance with the resource basis, target market demands and postulates defined by the developmental model (desired direction of development), taking into account realistic possibilities of positioning in the market.

Penetration into new markets, coupled with the construction of a high quality picture of the destination, greatly facilitates filling in of the vacant market niches and the achievement of competitive positioning based on the experience economy elements.

\section{Findings}

The quantification of tourist valorisation is often equated with the economic valorisation, which includes not only the grade of the existing value, but also the creation of the new one. Tourist valorisation includes a qualitative and quantitative grade of the value of tourist motives and cannot be identified with the economic valorisation.

Generalisation of evaluation can be expressed by means of the below stated equations, and that for the tourist seasons of 2007., 2010. and 2012. The research results are illustrated by points ranging from 1 to 10 , in the numerical form. Spatial valorisation by tourists is, in its major part, a subjective and emotional experience which has to be taken into consideration as a corrective factor of findings which are obtained by the application of the type equation.

Review of the results generated by the research in the area of the Municipality of Fažana are obtained by means of the sum of internal and external factors.

The results obtained by the research, by which valorisation of destination external and internal factors was carried out, notices that the Municipality of Fažana, as a tourist destination, realises 62 points out of the possible 80 in the year 2007, has 56 realised points in the year 2010 and 54 realised points in the year 2012 . Realised results interpret that the current position of the tourist offer of Fažana, as a tourist destination, are in line with the natural and cultural potentials of the Municipality. Also, they point to an attempt to systematically develop a more quality tourist offer, with the start of building of a recognisable tourist product which has been, however, stagnating for the last three years. Such a trend points to a correctly conducted economic valorisation of the potentials of the Municipality of Fažana, which are an integral part of the tourist offer. The trend negativity is reflected in the statics and it is an extension of the pronounced inflexibility of the tourist offer elements. Such a situation emanates from non-existence of the DMO, which would, by its action, correct the negativities in the tourist destination management. Also, it would have a direct influence on the DMC within the destination, as well as on the ultimate improvement of quality of the entire tourist product itself.

In order for tourist potentials to be correctly included in the economic valorisation, it is necessary for the tourist workers, together with the local self-government and domestic population, to do the destination promotion in accordance with the tourist offer elements. The planning of the future development, therefore, should be directed to those aspects which have been graded low in the valorisation, but equally valorise those which were ranked high, which are insufficiently economically exploited.

The research on satisfaction with the tourist offer elements, conducted within the destination and according to the global perception by all structures of surveyed tourists and certain tourist offer elements have been ranked, as shown in Table 4 below.

The research results confirm the understanding that the tourist product is outdated (contents) and that innovative interventions for the purpose of its adjusting to the modern demands of the target tourist market need to be deployed. This 
also imposes a need for an urgent destination management to be established on the partnership relationships, whose task is to raise the destination organisation to a higher level and to better valorise recognisable resources, which are accepted and supported by the tourist offer users (space, resources, environment, personnel, safety, etc.). In other words, to form a rational valorisation chain of the destination tourist offer.

Competitiveness imposes a need to sell an integral service, which, on the other hand, aggregates the quality of the entire destination offer due to the fear of fall in prices. If the exchange value conditionally becomes an experience, with destination repositioning, maximisation of the foreign currency influx will also be achieved and the level of discretionary expenditure in the destination will also be higher.

In positioning of a tourist offer, the competitiveness category becomes dominant in relation to the comparative advantages category. Tourist product repositioning, as a consequence of tourist offer repositioning, together with the influence on the creation of a destination tourist image/identity, has an impact on structural changes in both qualitative and quantitative forms of the complete tourist product. It is, therefore, necessary to systematically organise tourism development, with quantitative and qualitative developments of economic businesses, whose output is an integral element of the tourist product, in order to achieve multiplicative tourism effect. Such a systematic approach in the implementation of the principles of the experience economy leads to adoption of the principles of the new economy, applied to tourism at both macro and micro levels, where, with the change in the resource base and monitoring of the economic growth rate, it complements the economic development with, currently slowed down, formation of a rational valorisation of the tourist offer chain of the Municipality of Fažana.

\section{Discussion}

Modern tourism trends impose increasingly frequent structural changes. The answer to the changes caused in such a way is manifested by product differentiation, level of education and training, new organisational relationships, use of technologies and innovations, as well as by the manner of communication between emissive and receptive markets.

The world expansion of travelling to a destination with standard tourist products has reached its peak, i.e. destinations with a sole motive of the sun and the sea, as well as a passive holiday, as a motive for arrival, while the remaining tourist resource basis is insufficiently appreciated. The positioning of the tourist offer and tourist product of the Municipality of Fažana, based on quality and the experience economy, coupled by the original identity and specific characteristics, multiplies socio-economic benefits from tourism and leads to the progression of the added value, with efficient and sustainable valorisation of the tourist resource basis.

The development of tourist products based on experience as the key exchange value requires an interdisciplinary approach, which, with applied marketing activities and competitive positioning by means of identity affirmation, leads to the positioning of tourist offer from the aspect of the experience economy.

The competitive positioning of Fažana as a tourist destination must take into account the constant algorithm of the experience economy, communicational attributes and economically rational tourist offer valorisation chain. Taking into consideration the postulates of the experience economy, which facilitates the achievement of competitive advantage on the basis of differentiation by quality, such a concept for the Municipality of Fažana reflects advantage in (tourist) experiences promotion, based on unique attributes which do not utilise the competitive destination of the area (amphora, sardines, and heritage). It is due to the nature of the resource basis itself that the experience dimension of the entire tourist offer of the Municipality of Fažana should represent a dominant direction in consolidation of the tourist offer elements. Marketing actions must omit the stress from the traditional elements of receptive tourism and focus on the exploitation and promotion of the dominant resources, whose value is exceptionally high and/or on the unrepeatable quality of the local destination identity.

The positioning of the Municipality of Fažana as a tourist destination should be carried out while taking into account the current recognisability of the destination through the motives of the sardine and amphora, affirming the principle of differentiation by quality and achievement of premium prices on the micro level. By the destination geographical position within the Istrian peninsula, resource base is valorised, which competitive tourist offers (destinations of the Mediterranean Basin) cannot valorise.

From the above quoted, it can be concluded that the positioning of the tourist offer of the Municipality of Fažana, on the principles of competitiveness and experience economy, implied a higher level of achievement of the tourist offer added value, with the conception of a rational valorisation chain of the tourist offer elements. 


\section{References}

Boswijk, A, Thijssen, J.P.T., Peelen, E. (2005) A new perspective on the experience economy: Meaningful experience, Amsterdam: Pearson education.

Bueno, A.P., (1999) Competitiveness in the tourist industry and the role of the Spanish public administrations, Turizam, 47(4), 316-331.

Dujmović, M., Vitasović, A. (2009) Changing world of tourism, 18.th annual research conference, Council for Hospitality Management Education, Eastbourne, United Kingdom.

Dujmović, M., Vitasović, A. (2009) Tourism and the New Mobility paradigm, ATHE annual conference Navigatin Shifting Sanda and Moving Mountains: New Paradigms for Tourism and Tourism Education, 2009, Losehill Hall Peak District National Park, United Kingdom. 299.

Dwyer, L., Forsyth, P., Rao, P. (1999) Tourism price competitiveness and journey purpose, Turizam, 47(4), 283-

Gržinić, J., Vitasović, A., (2007) The role of Tourism in the Development of Employment in Istria, Economic Analysis, 40(1-2) Spring, Beograd: Ekonomski fakultet Beograd. str. 29-37.

Horvat, Đ., Kovačević, V. (2004) Clusteri-put do konkurentnosti, Zagreb: M.E.P. consult.

Kunst, I., Poljanec-Borić, S- (2008) Pozicioniranje turističke ponude, Srbija. Turizam, 56(1), 93-108.

Oh, H., Fiore, A., Jeoung, M. (2007) Measuring Experience Economy Concepts: Tourism Applications, Journal of Travel Research, 46 Novembar,119-132.

Pine, B. J., i Gilmore, J. H. (1999) The experience economy. Boston: Harvard University Press.

Prahalad, C.K., Ramaswamy, V. (2004) The Future competition, Co-creating unique value with customers, Boston: Harvard business School Press.

Stiglitz, E. J., (2000) Economics of the Public Sector, New York, W. W. Norton.

Vitasović, A. (2008) Cultural branding in Croatian tourism and in European Union, u Knowledge for sustainable development, International conference on organizational science development, University of Maribor, Portorož, Slovenia. 130.

Vitasović, A. (2008) Fažana kao destinacija kulturnog turizma, u Fažanski libar 3, Fažana: AMPress, str.117-

Table 1. Illustration of internal and external value factors

\begin{tabular}{|l|l|}
\hline Variables & Form \\
\hline X-sum of internal factor evaluation & \\
A- urbanisation evaluation & $X=(A)+(B)+(C)+(D)$ \\
B-infrastructural evaluation & \\
C- equipment and services evaluation & \\
D-inherent characteristics evaluation & \\
\hline$\underline{\text { Y-sum of external factor value evaluation }}$ & \\
E- accessibility evaluation & $Y=(E)+(F)+(G)+(H)$ \\
F- resource specific quality evaluation & \\
G- vicinity of emissive centres & \\
H- significance evaluation & \\
\hline
\end{tabular}

Source: Prepared by authors 
Table 2. Internal factor evaluation

\begin{tabular}{|l|l|}
\hline Internal factors & Results \\
\hline B - Infrastructural evaluation & $\begin{array}{l}\text { Development of tourist infra and supra-structure defined by the Municipality } \\
\text { documents for the future period }\end{array}$ \\
\hline C - Equipment and services evaluation & Satisfactory, with additional interventions. \\
\hline D - Inherent characteristics evaluation & $\begin{array}{l}\text { Area attractiveness and a large platform which enables the creation of tourist } \\
\text { offer. } \\
\text { Low degree of air, water and soil pollution, as well as a climate which } \\
\text { facilitates the development of all forms of tourism - favourable from the aspect } \\
\text { of capacity occupancy throughout the whole year. } \\
\text { Rich animal fund with clearly determined hunting policy and a rich fishing fund, } \\
\text { which is, at the same time, proof of sea water cleanliness }\end{array}$ \\
\hline
\end{tabular}

Table 3. Internal factor $(\mathrm{X})$

\begin{tabular}{|l|l|l|l|}
\hline & Year 2007 & Year 2010 & Year 2012 \\
\hline & $\mathrm{X}=(\mathrm{A})+(\mathrm{B})+(\mathrm{C})+(\mathrm{D})$ & $\mathrm{X}=(\mathrm{A}) 7+(\mathrm{B}) 7+(\mathrm{C}) 4+(\mathrm{D}) 7$ & $\mathrm{X}=(\mathrm{A}) 6+(\mathrm{B}) 7+(\mathrm{C}) 4+(\mathrm{D}) 6$ \\
\hline & $\mathrm{X}=(\mathrm{A}) 7+(\mathrm{B}) 7+(\mathrm{C}) 5+(\mathrm{D}) 8$ & 25 & 23 \\
\hline$\sum X$ & 27 & 25 & \\
\hline
\end{tabular}

Source: Prepared by authors

* In internal factors the results are obtained by award of points ranging from the highest to the lowest grade.

Table 4. External factor evaluation

\begin{tabular}{|l|l|}
\hline External factors & Result \\
\hline E - Accessibility evaluation & $\begin{array}{l}\text { Good geographic and traffic situation } \\
\text { Accessibility to all localities }\end{array}$ \\
\hline G - Vicinity of emissive centres & Relative vicinity of emissive centres \\
\hline H-Significance of resources & Unity of the elements of tourist offer \\
\hline
\end{tabular}

Source: Prepared by authors 
Table 5. External factors ( $Y$ )

\begin{tabular}{|l|l|l|l|}
\hline & Year 2007 & Year 2010 & Year 2012 \\
\hline & $Y=(E)+(F)+(G)+(H)$ & $Y=(E) 9+(F) 7+(G) 9+(H) 6$ & $Y=(E) 10+(F) 7+(G) 9+(H) 5$ \\
\hline & $Y=(E) 10+(F) 9+(G) 9+(H) 7$ & 31 \\
\hline$\sum Y$ & 35 & 31 & 31 \\
\hline
\end{tabular}

Source: Prepared by authors

Table 6. Ranking of tourist offer elements

\begin{tabular}{|c|c|c|c|}
\hline Rank & Year 2007 & Year 2010 & Year 2012 \\
\hline 1. & Space, resources, environment & Space, resources, environment & Space, resources, environment \\
\hline 2. & Population, employed & $\begin{array}{l}\text { Recognisability, safety, being } \\
\text { informed }\end{array}$ & $\begin{array}{l}\text { Recognisability, safety, being } \\
\text { informed }\end{array}$ \\
\hline 3. & $\begin{array}{l}\text { Recognisability, safety, being } \\
\text { informed }\end{array}$ & Population, employed & Population, employed \\
\hline 4. & Destination organisation & Contents & Contents \\
\hline 5. & Contents & Destination organisation & Destination organisation \\
\hline
\end{tabular}

Source: Prepared by authors

Figure 1. Method of TOWS matrix preparation

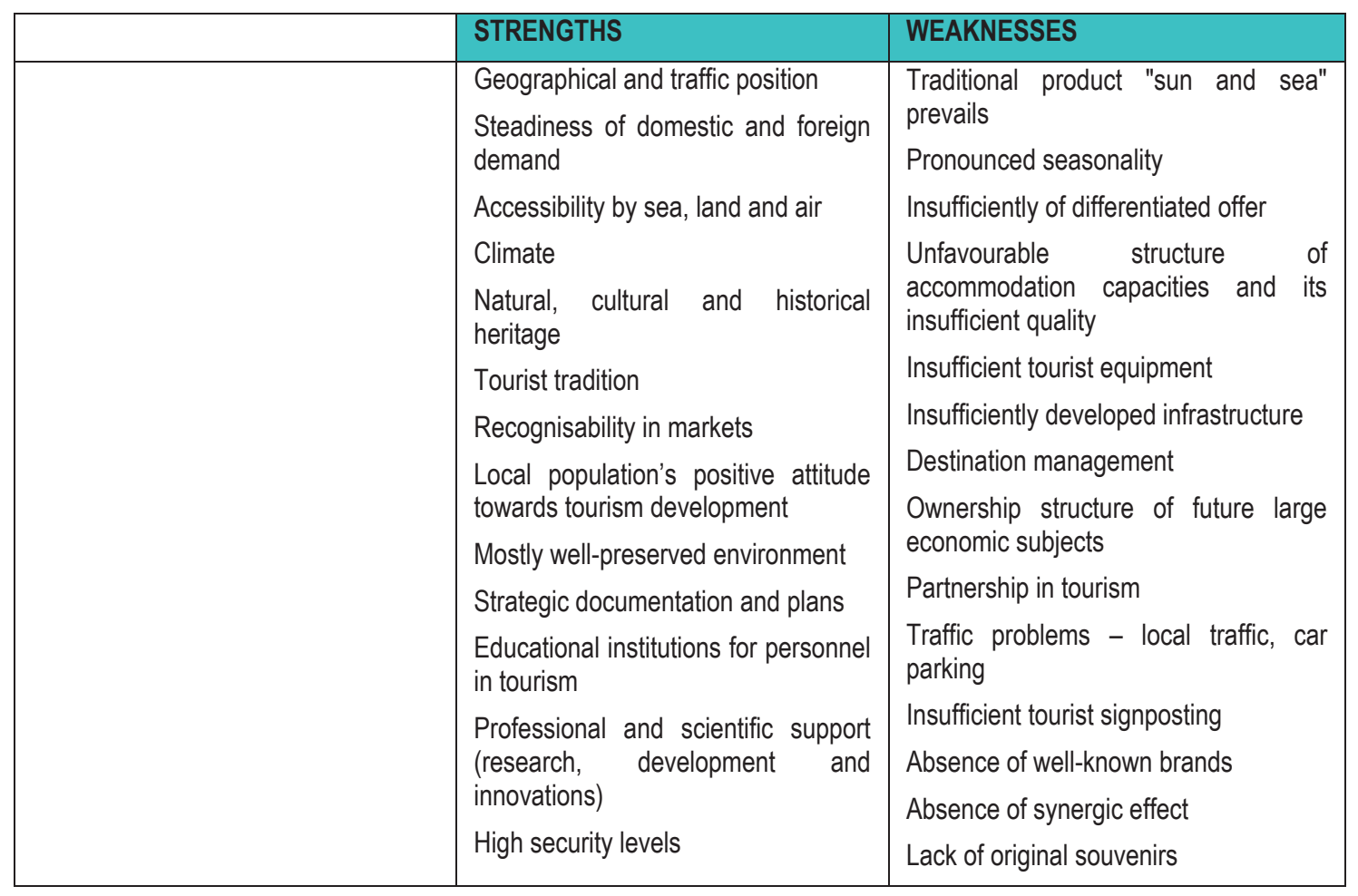




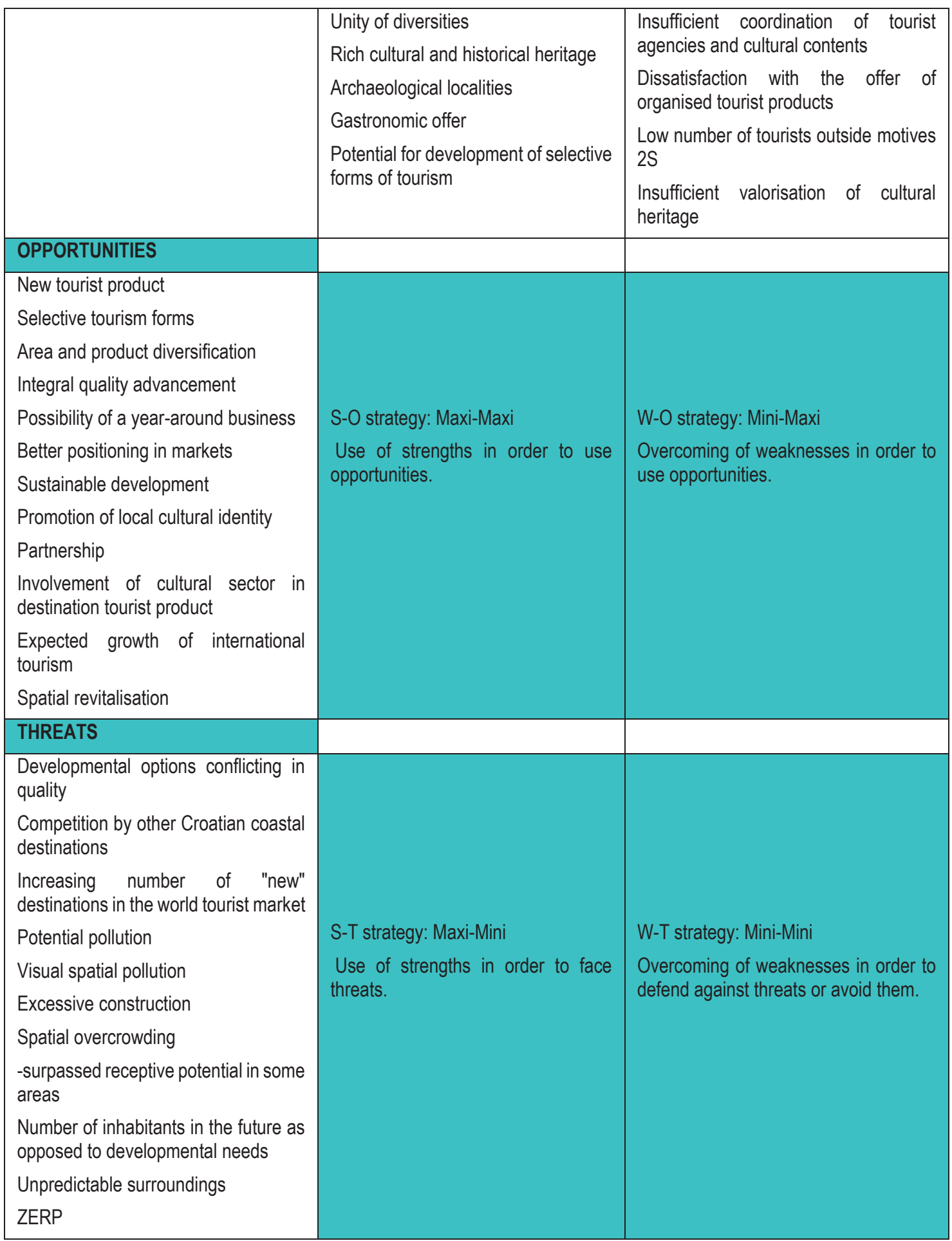

Source: Preparation and conclusions by authors 